\title{
Mystery ring: a case of TIPS stent migration
}

\author{
Murad Abdelsalam, ${ }^{1}$ Sruthi Vellanki, ${ }^{2}$ Anup Kumar Ashwini Kumar Trikannad, ${ }^{2}$ \\ Michele Degregorio ${ }^{1}$
}

'Department of Cardiology, Saint Joseph Mercy Oakland Hospital, Pontiac, Michigan, USA ${ }^{2}$ Department of Internal Medicine, Saint Joseph Mercy Oakland Hospital, Pontiac, Michigan, USA

Correspondence to Dr Murad Abdelsalam, Murad.abdelsalam@gmail.com

Accepted 4 December 2017

\section{(1) crossark}

To cite: Abdelsalam M, Vellanki S,

Ashwini Kumar Trikannad AK, et al. BMJ Case Rep Published Online First: [please include Day Month Year]. doi:10.1136/bcr-2017 222830

\section{DESCRIPTION}

We present a 50-year-old man with history of end-stage liver disease secondary to hepatitis C, who frequently presents to the hospital with ascites. He recently underwent Trans jugular Intrahepatic Portosystemic Shunt (TIPS) stent placement after becoming resistant to diuresis and large volume therapeutic paracentesis. He presented to the emergency room with altered mental status due to hepatic encephalopathy. On physical exam, he was noted to have a systolic murmur; hence, a transthoracic echocardiogram was ordered. It showed an echo dense ring-like shadow in the right atrium close to intra-atrial septum (figure 1). Transoesophageal echocardiogram was obtained for better visualisation, and it showed a migrated TIPS stent entering the right atrium from the inferior vena cava with its cephalad end close to the intraatrial septum (figure 2). There was no evidence of mechanical complication related to stent migration by echocardiography. The patient declined percutaneous retrieval. He was doing fine on subsequent follow-ups.

Stent misplacement and migrations are rare but potentially life-threatening complications of TIPS. Prior case reports in the literature show that stents displaced to distal areas such as right atrium, right ventricle and pulmonary artery. It can also cause conduction abnormalities, valvular damage, perforation and death. ${ }^{1-3}$

Literature review showed one similar case diagnosed by echocardiography in a 57-year-old male patient, who had cardiac ectopy, where the misplaced stent did not cause acute mechanical complication and was managed in the outpatient setting. $^{2}$

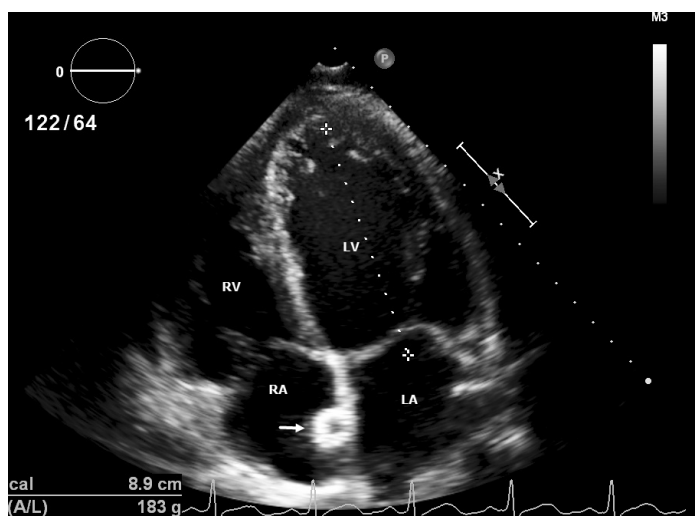

Figure 1 Transthoracic echocardiogram, apical four view, showing right atrial ring-like structure (white arrow) close to the intra-atrial septum. LA, left atrium; $L V$, left ventricle; $R A$, right atrium; $R V$, right ventricle; SVC, superior vena cava.

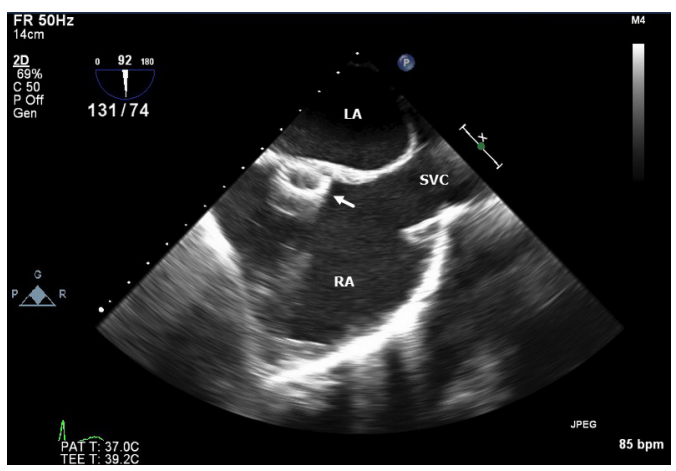

Figure 2 Transoesophageal echocardiogram, transcaval view, showing cephalad end of the migrated stent (white arrow) in the right atrium close to the intra-atrial septum.

Our case highlights the role of echocardiography to diagnose such complication of TIPS procedure and evaluate for its consequences. Echocardiography could also help guide the treatment approach including endovascular or surgical stent retrieval.

\section{Learning points}

- Stent misplacements and migrations are rare complication of Trans jugular Intrahepatic Portosystemic Shunt procedure.

- Echocardiography is a helpful tool in diagnosing and guiding treatment options.

- Percutaneous retrieval is feasible and can prevent fatal complication of stent migration.

Contributors MA and SV wrote the initial manuscript. MD and AKAKT conducted the literature review and edited the paper, including image editing and paper design. MA and SV contributed to data collection and image editing as well. All authors read and approved the final manuscript.

Competing interests None declared.

Patient consent Obtained.

Provenance and peer review Not commissioned; externally peer reviewed

(C) BMJ Publishing Group Ltd (unless otherwise stated in the text of the article) 2017. All rights reserved. No commercial use is permitted unless otherwise expressly granted.

\section{REFERENCES}

1 Ripamonti R, Ferral H, Alonzo M, et al. Transjugular intrahepatic portosystemic shunt-related complications and practical solutions. Semin Intervent Radiol 2006;23:165-76.

2 Wendler C, Shoenberger JM, Mailhot T, et al. Transjugular Intrahepatic Portosystemic Shunt (TIPS) Migration to the Heart Diagnosed by Emergency Department Ultrasound. West J Emerg Med 2012;13:525-6.

3 Ward P, Spencer KT. Migration of a transjugular intrahepatic portosystemic shunt (TIPS) stent: evaluation by transesophageal echocardiography. J Am Soc Echocardiogr 2000;13:949-50. 
Copyright 2017 BMJ Publishing Group. All rights reserved. For permission to reuse any of this content visit http://group.bmj.com/group/rights-licensing/permissions.

BMJ Case Report Fellows may re-use this article for personal use and teaching without any further permission.

Become a Fellow of BMJ Case Reports today and you can:

- Submit as many cases as you like

- Enjoy fast sympathetic peer review and rapid publication of accepted articles

Access all the published articles

- Re-use any of the published material for personal use and teaching without further permission

For information on Institutional Fellowships contact consortiasales@bmjgroup.com

Visit casereports.bmj.com for more articles like this and to become a Fellow 